\title{
PENGEMBANGAN MEDIA PEMBELAJARAN INTERAKTIF MENGGUNAKAN SOFTWARE ADOBE FLASH MATERI BUMI DAN ALAM SEMESTA
}

\author{
${ }^{1}$ Nia Widiyastuti, ${ }^{2}$ Slameto, \& ${ }^{3}$ Elvira Hoesein Radia \\ e-mail:292014035@student.uksw.edu \\ Universitas Kristen Satya Wacana
}

Jalan Diponegoro 52-60 Salatiga, Jawa Tengah

\begin{abstract}
Abstrak: Penelitian ini bertujuan untuk mengembangkan media pembelajaran interaktif dengan menggunakan software Adobe Flash Professional CS6 pada materi Bumi dan Alam Semesta kelas III SD. Jenis penelitian ini adalah penelitian dan pengembangan yang dilaksanakan dengan menggunakan model pengembangan Borg and Gall yang dimodifikasi menjadi tujuh langkah pengembangan, yaitu (1) pengumpulan data; (2) perencanaan; (3) pengembangan draft produk; (4) uji coba lapangan awal; (5) merevisi hasil uji coba lapangan awal; (6) uji coba lapangan; dan (7) menyempurnakan produk. Penelitian dilakukan pada bulan April 2018 di dua sekolah dasar di Salatiga. Subjek penelitian melibatkan 10 siswa kelas III SD pada uji coba lapangan awal dan 32 siswa kelas III SD pada uji coba lapangan. Hasil uji validitas dari ahli media diperoleh nilai rata-rata 3,9 dengan kategori baik. Hasil uji validitas dari ahli materi diperoleh nilai rata-rata 2,95 dengan kategori cukup baik. Hasil kuesioner respon siswa pada uji coba lapangan awal menujukkan nilai rata-rata 4,5 dan hasil kuesioner respon siswa pada uji coba lapangan menujukkan nilai rata-rata 4,6 dengan kategori sangat baik. Hasil kuesioner respon guru menunjukkan rata-rata 5,0 pada uji coba lapangan awal dan 4,8 pada uji coba lapangan dengan kategori sangat baik. Berdasarkan validasi ahli materi, ahli media, hasil kuesioner respon siswa dan guru, media pembelajaran interaktif yang dikembangkan menggunakan software Adobe Flash materi Bumi dan Alam Semesta layak digunakan dalam pembelajaran kelas III SD dan dapat meningkatkan ketertarikan siswa terhadap materi pembelajaran serta menumbuhkan minat belajar siswa.
\end{abstract}

Kata-kata kunci: media pembelajaran interaktif, software Adobe Flash, materi bumi dan alam semesta

\section{DEVELOPMENT OF INTERACTIVE MEDIA USING ADOBE FLASH SOFTWARE ON EARTH AND UNIVERSE MATERIALS}

\begin{abstract}
The study aims to develop interactive learning media using Adobe Flash Professional CS6 software on Earth and Universe materials for third-grader students in primary school. The types of the study are research and development which carried out by using Borg and Gall's model development and modified into 7 development steps, which are (1) research and information collecting; (2) planning; (3) develop preliminary form of product; (4) preliminary field testing; (5) main product revision; (6) main field testing; and (7) operasional product revision. The study was conducted on April 2018 in two primary schools in Salatiga. The subjects of the study involved 10 third-grader students of primary school on preliminary field testing and 32 third-grader students of primary school on the main field testing. The results of validity test from the media expert obtained an average scores of 3,9 with a good category. The results of validity test from the material expert obtained average scores of 2.95 with good enough category. The result of students questionnaire on preliminary field testing showed the average scores of 4.5 and the result of the students questionnaire on main field testing showed the average scores of 4,6 with a very good category. Then, the result of teachers questionnaire showed an average of 5.0 on preliminary field testing and 4.8 on main field testing with a very excellent category. Based on the validation of material experts, media experts, the results of questionnaire responses of both students and teachers, interactive learning media that developed by adobe flash software of earth and the universe materials are suitable in learning for third grader of Primary School students and can enhance students' interest in learning materials and build students' learning motivation.
\end{abstract}

Keywords: interactive learning media, Adobe Flash software, earth and universe materials 


\section{PENDAHULUAN}

Dalam Undang-Undang No. 20 Tahun 2003 pasal 1 ayat 1 , menyatakan bahwa pendidikan adalah usaha sadar dan terencana untuk mewujudkan suasana belajar dan proses pembelajaran agar siswa dapat aktif mengembangkan potensi dirinya untuk memiliki kekuatan spiritual keagamaan, pengendalian diri, kepribadian, kecerdasan, akhlak mulia, serta keterampilan yang diperlukan dirinya, masyarakat, bangsa serta negara. Melalui program yang diatur sedemikian rupa, peran pendidikan adalah membentuk kepribadian warga negaranya agar menjadi generasi yang sadar dan peduli terhadap kemajuan bangsa, mampu berpartisipasi dan bersaing di era globalisasi.

Dampak era globalisasi sangat jelas pengaruhnya bagi sendi kehidupan manusia di seluruh dunia, persaingan yang terbuka disebabkan karena tembok pembatas antara bangsa dan negara di dunia seolah telah berhasil dirobohkan (Slameto dkk, 2016). Tidak hanya itu, pendidikan di era globalisasi menuntut adanya dasar-dasar pendidikan yang kokoh sesuai dengan konsep long life education seiring dengan berkembangnya ilmu pengetahuan di mana teknologi berperan sangat penting dalam setiap komponen kehidupan (Sa'ud, 2012). Kemajuan teknologi saat ini memberikan dampak positif dalam bidang pendidikan, bahan ajar tidak lagi terbatas pada media cetak namun juga dapat diakses melalui banyak cara, memungkinkan untuk menyajikan materi dengan cara yang menarik. Penyajian materi yang dikemas menarik dapat meningkatkan kualitas pembelajaran menjadi lebih baik (Apriyani, 2015). Selain buku, guru dituntut untuk dapat mengaplikasikan berbagai hal di lingkungan siswa sebagai sumber belajar pada setiap proses pembelajaran(Prayogo, 2015).

Pembelajaran saat ini merupakan pembelajaran abad 21 atau abad pengetahuan yang menjadi landasan bagi segala aspek kehidupan (Hasan, 2003). Pemilihan metode belajar dan pembelajaran yang tepat menjadi hal yang dinilai sangat penting bagi seorang guru di abad 21 (Suyono \& Hariyanto, 2014). Agar materi pembelajaran dapat dipahami oleh siswa dibutuhkan keterampilan mengelola kelas yang baik oleh seorang guru, inilah yang menjadikan seorang guru harus mampu menentukan sebuah metode yang tepat dalam proses pembelajaran (Slameto, 2011). Salah satu yang perlu diperhatikan dalam memilih metode yang tepat adalah dengan memperhatikan dan menyesuaikan dengan karakteristik siswa.

Usia siswa SD saat ini termasuk dalam generasi
$Z$ berdasarkan diperkenalkannya teori 5 generasi yang populer di kalangan pendidik setelah perang dunia II. Salah satu karakteristik generasi $\mathrm{Z}$ adalah fasih teknologi, mampu dengan mudah mengoperasikan teknologi informasi beserta aplikasinya (Slameto, 2015). Pemanfaatan teknologi informasi khususnya komputer dalam pembelajaran dapat menjadi salah satu metode yang tepat. Selain materi pembelajaran yang disajikan dapat lebih menarik bagi siswa, ini juga sesuai dengan karakteristik siswa sebagai generasi $\mathrm{Z}$ yang fasih teknologi. Penggunaan teknologi informasi dalam pembelajaran di sekolah dasar dapat membantu menambah ketertarikan siswa terhadap materi pembelajaran serta membantu siswa agar terbiasa dengan perkembangan teknologi yang sangat pesat di era globalisasi.

Salah satu pengaplikasian teknologi komputer dalam pembelajaran di sekolah adalah dengan menggunakan media pembelajaran yang melibatkan TIK, khususnya komputer. Media pembelajaran merupakan sesuatu yang dapat digunakan sebagai penyalur pesan di mana dalam lingkup pendidikan pesan tersebut adalah berupa materi pembelajaran sehingga siswa dapat mencapai tujuan belajar (Mawardi, 2018). Media pembelajaran interaktif adalah media pembelajaran yang menyajikan video rekaman berisikan materi pembelajaran dengan menggunakan komputer sebagai perangkat utama dan dapat memberikan respon langsung kepada siswa (Indriana, 2011). Adanya fasilitas yang memadai di sekolah-sekolah, seperti tersedianya laboratorium komputer sangat mendukung untuk dikembangkan media pembelajaran dengan menggunakan komputer sebagai perangkat utama.

Hal yang perlu diperhatikan selanjutnya adalah menyesuaikan materi dengan media pembelajaran yang akan digunakan. Media pembelajaran membantu menghadirkan berbagai objek yang berbahaya dan sulit ditemukan dalam lingkungan belajar siswa, menampilkan objek yang terlalu besar maupun kecil, memperlihatkan gerakan yang terlalu cepat atau lambat misalnya proses alamiah yang terjadi di lingkungan alam (Indriana, 2011).

Lingkungan alam merupakan lingkungan yang sangat dekat dengan manusia. Mempelajari ilmu pengetahuan alam adalah sesuatu yang menarik bagi sebagian orang, karena ilmu pengetahuan alam (IPA) merupakan disiplin ilmu yang keberadaannya sangatlah penting bagi manusia. Belajar IPA akan memberi pengetahuan kepada siswa tentang dunia tempat hidup dan bagaimana harus bersikap terhadap alam sebagai makhluk. IPA menanamkan satu sikap 
hidup yang ilmiah, pentingnya sikap ilmiah sehingga siswa memiliki pengetahuan yang teratur, melatih keterampilan, dan memiliki rasa ingin tahu yang tinggi, kemampuan mengamatinya terlatih serta pendapatnya berkembang (Sukarno, 1981).

Belajar IPA di sekolah dasar tidak hanya melatih keterampilan siswa tetapi juga mendorong siswa untuk belajar memahami dan mengamati, sehingga apa yang dipahami akan dapat mereka terapkan dalam kehidupan sehari-hari (Radia, 2016). Pembelajaran di sekolah dasar akan efektif jika siswa turut aktif melibatkan diri dalam proses pembelajaran. Sesuai prinsip yang tertuang dalam Depdikbud dalam Sanoto \& S. Pulungan (2014) tentang prinsip yang perlu diterapkan agar terwujud situasi belajar yang sesuai adalah prinsip motivasi, latar, menemukan, belajar sambil bekerja, belajar sambil bermain dan prinsip hubungan sosial. Selain itu, salah satu faktor yang menentukan keberhasilan pembelajaran IPA adalah kemampan dasar dari siswa dan guru itu sendiri, bagaimana seorang guru mampu menyampaikan materi dengan baik sehingga dapat diterima oleh siswa yang memiliki kemampuan yang beragam (Nanda, 2010). Berdasarkan uraian tersebut, tujuan pembelajaran IPA akan tersampaikan kepada siswa jika materi pada pembelajaran IPA disajikan dengan cara yang tepat yaitu dengan memanfaatkan media pembelajaran pada proses pembelajaran.

Penelitian ini bertujuan untuk mengembangkan media pembelajaran interaktif yang dapat digunakan untuk siswa kelas III SD, serta untuk mengetahui kelayakan dari media pembelajaran interaktif yang dikembangkan untuk siswa kelas III SD. Media pembelajaran ini dikembangkan dengan menggunakan software Adobe Flash Professional CS6. Adobe Flash adalah software berbasis vektor yang digunakan untuk membuat berbagai animasi. Software ini mampu mengolah teks dan objek dengan efek tiga dimensi. Software yang didesain khusus oleh adobe dan program aplikasi standar authoring tool professional yang difungsikan untuk membuat animasi untuk kepentingan dalam pengembangan dan pembangunan situs web yang interaktif (MADCOMS, 2013).

Penelitian dan pengembangan ini diharapkan dapat berhasil seperti yang dilakukan oleh Yunita (2017) yang bertujuan mengetahui kelayakan dari media yang dikembangkan. Hasil penelitian ini adalah media yang dihasilkan layak dan dapat memperjelas materi pembelajaran. Penelitian yang serupa dilakukan oleh Farida Hasan (2017) yang juga mengembangkan media pembelajaran menggunakan software Adobe Flash untuk meningkatkan hasil belajar siswa.

\section{METODE PENELITIAN}

Penelitian ini merupakan penelitian dan pengembangan. Penelitian dan pengembangan ini menggunakan model pengembangan menurut Borg and Gall yang dimodifikasi menjadi tujuh langkah pengembangan. Tujuh langkah pengembangan tersebut yaitu (1) penelitian dan pengumpulan data, (2) perencanaan, (3) pengembangan draft produk, (4) uji coba lapangan awal, (5) revisi hasil uji coba lapangan awal, (6) uji coba lapangan, dan (7) penyempurnaan produk hasil uji coba lapangan.

Pada tahap penelitian dan pengumpulan data yang dilakukan adalah melakukan observasi di sekolah. Pada tahap perencanaan melakukan analisis kebutuhan, menentukan subjek pengguna produk, identifikasi materi yaitu materi Bumi dan Alam Semesta pada mata pelajaran IPA kelas III SD semester 2. Tahap selanjutnya adalah mengembangkan draft produk awal, draft produk awal yang telah disusun kemudian diuji oleh ahli media dan ahli materi, draft produk awal direvisi sesuai dengan saran para ahli. Langkah selanjutnya adalah melakukan uji coba lapangan awal, hasil uji coba lapangan awal dijadikan dasar dalam merevisi produk. Produk yang sudah direvisi kemudian dilakukan uji coba lapangan. Hasil uji coba lapangan dijadikan dasar menyempurnakan produk hingga diperoleh produk akhir berupa media pembelajaran interaktif yang dikembangkan menggunakan software Adobe Flash materi Bumi dan Alam Semesta untuk kelas III SD.

Desain uji coba produk yang dilakukan terdiri dari tiga kali uji coba, yaitu (1) uji ahli; (2) uji coba lapangan awal; dan (3) uji coba lapangan. Teknik uji ahli terdiri dari uji media dan uji ahli materi. Dalam penelitian ini melibatkan 10 siswa kelas III SD pada uji coba lapangan awal dan melibatkan 32 siswa kelas III SD pada uji coba lapangan yang dilakukan pada bulan April 2018. Teknik nontes dalam pengumpulan data terdiri dari kuesioner respon siswa dan respon guru yang bertujuan untuk mengetahui respon siswa dan respon guru terhadap media pembelajaran interaktif yang dikembangkan.

Instrumen pengumpulan data penelitian ini terdiri dari lembar validasi ahli yang diiisi oleh ahli materi dan ahli media, lembar kuesioner respon siswa yang diisi oleh siswa, dan lembar kuesioner respon guru yang diisi oleh guru kelas. Teknik analisis data yang digunakan adalah teknik analisis deskriptif. Frekuensi tiap skor dihitung untuk mengetahui persentase dari masing-masing kategori. Skor data kuantitatif kemudian diinterpretasikan ke dalam data 
kualitatif menggunakan acuan konversi skala Likert (Arikunto, 2013).

Tabel 1

Pedoman Konversi Skor Kuantitatif Skala 5 Menjadi Data Kualitatif

\begin{tabular}{lll}
\hline \multicolumn{1}{c}{ Interval skor } & \multicolumn{1}{c}{ Perhitungan } & \multicolumn{1}{c}{ Kategori } \\
\hline$($ Mean $+1,5 \mathrm{SD})<\mathrm{x}$ & $\mathrm{x}>4,01$ & Sangat baik \\
$($ Mean $+0,5 \mathrm{SD})<\mathrm{x} \leq($ Mean $+1,5 \mathrm{SD})$ & $3,34<\mathrm{x} \leq 4,01$ & Baik \\
$($ Mean $-0,5 \mathrm{SD})<\mathrm{x} \leq($ Mean $+0,5 \mathrm{SD})$ & $2,66<\mathrm{x} \leq 3,34$ & Cukup \\
$($ Mean $-1,5 \mathrm{SD})<\mathrm{x} \leq($ Mean $-0,5 \mathrm{SD})$ & $1,99<\mathrm{x} \leq 2,66$ & Kurang \\
$\mathrm{x} \leq($ Mean $-1,5 \mathrm{SD})$ & $\mathrm{x}<1,99$ & Sangat kurang \\
\hline
\end{tabular}

\section{HASIL DAN PEMBAHASAN}

Hasil observasi dan wawancara yang dilakukan pada tahap penelitian dan pengumpulan data di beberapa sekolah di Salatiga, menunjukkan dibutuhkannya media pembelajaran interaktif yang memanfaatkan komputer sebagai perangkat utama. Hal ini didasarkan karakter siswa yang fasih terhadap teknologi. Pemilihan metode pembelajaran yang tepat sangat berperan dalam keberhasilan suatu pembelajaran. Cara penyampaian materi yang dapat menarik bagi siswa sehingga menumbuhkan minat siswa untuk belajar. Pemilihan metode hendaknya disesuaikan dengan karakteristik siswa. Penyajian materi yang menarik dapat meningkatkan ketertarikan siswa terhadap pembelajaran sehingga menumbuhkan minat siswa untuk belajar. Selain itu, adalah pentingnya pengenalan dan pembiasaan penguasaan TIK dalam proses pembelajaran, serta didukung tersedianya fasilitas yang memadai seperti laboratorium komputer serta kemampuan siswa dan guru dalam mengoperasikan perangkat komputer.

Setelah mengetahui kebutuhan sekolah, langkah selanjutnya adalah merencanakan rancangan produk yaitu produk media pembelajaran interaktif yang dikembangkan dengan menggunakan software Adobe Flash Professional CS6. Materi dalam media ini adalah materi Bumi dan Alam Semesta kelas III SD semester 2. Model CBI yang digunakan adalah model tutorial. Model tutorial merupakan model yang menyajikan materi dan soal latihan (Darmawan, 2012).

Pengembangan draft produk awal media pembelajaran interaktif yang di dalamnya memuat informasi standar kompetensi, kompetensi dasar, indikator, tujuan pembelajaran, dan materi pembelajaran bumi dan alam semesta yang disajikan dalam bentuk teks, gambar dan video, dilengkapi dengan latihan soal dan evaluasi. Media pembelajaran ini dirancang untuk dapat memberikan respon langsung kepada siswa berupa skor nilai yang diperoleh ketika siswa mengerjakan soal latihan dan evaluasi.

Draft produk awal kemudian diuji oleh ahli media dan ahli materi sebelum diuji cobakan ke lapangan. Penilaian ahli media terdiri dari tiga aspek yaitu aspek kualitas media, aspek kualitas instruksional media dan aspek kualitas teknis media. Rata-rata hasil penilaian ahli media adalah 3,9.

Tabel 2

Analisis Data Uji Ahli Media

\begin{tabular}{lc}
\hline \multicolumn{1}{c}{ Aspek } & Nilai \\
\hline Kualitas media & 3,0 \\
Kualitas instruksional media & 4,25 \\
Kualitas teknis media & 4,6 \\
\hline
\end{tabular}

Penilaian ahli materi terdiri dari aspek ketepatan materi dengan indikator pembelajaran dan kompetensi serta tujuan pembelajaran, keluasan materi, kelengkapan materi, dan kejelasan materi. Hasil penilaian dari ahli materi memperoleh nilai rata-rata 2,95.

Tabel 3

Analisis Data Uji Ahli Materi

\begin{tabular}{lc}
\hline \multicolumn{1}{c}{ Aspek } & Nilai \\
\hline Ketepatan & 4,0 \\
Keluasan & 3,0 \\
Kelengkapan & 3,0 \\
Kejelasan & 2,7 \\
\hline
\end{tabular}

Draft produk awal media pembelajaran interaktif kemudian direvisi sesuai saran dari para ahli. Setelah diperoleh validasi dari para ahli bahwa media pembelajaran interaktif ini layak digunakan, langkah selanjutnya adalah melakukan uji coba lapangan awal.

Uji coba lapangan awal dilakukan pada 10 siswa kelas III SD di Salatiga pada bulan April 2018. Data yang diperoleh pada tahap ini berupa angket respon siswa dan angket respon guru.

Tabel 4

Analisis Data Kuesioner Respon Siswa

\begin{tabular}{lc}
\hline \multicolumn{1}{c}{ Aspek } & Rata-rata \\
\hline Ketertarikan & 4,5 \\
Penyajian & 4,5 \\
Kualitas dan manfaat & 4,5 \\
Rasa ingin tahu & 4,5 \\
Kemauan berprestasi & 4,6 \\
\hline
\end{tabular}

Tabel 5

Analisis Data Kuesioner Respon Guru

\begin{tabular}{lc}
\hline \multicolumn{1}{c}{ Aspek } & Rata-rata \\
\hline Kesesuaian & 5,0 \\
Manfaat & 5,0 \\
\hline
\end{tabular}




\begin{tabular}{lc}
\hline \multicolumn{1}{c}{ Aspek } & Rata-rata \\
\hline Kelayakan & 5,0 \\
\hline
\end{tabular}

Berdasarkan analisis data tersebut, respon siswa dan guru terhadap media pembelajaran interaktif ini sangat baik yang ditunjukkan dengan perolehan nilai rata-rata pada angket respon siswa sebesar 4,5 dan nilai rata-rata pada angket respon guru adalah 5,0 berada pada kategori sangat baik.

Hasil kuesioner respon siswa dan respon guru kemudian dijadikan dasar untuk merevisi produk media pembelajaran interaktif. Berdasarkan saran dari guru kelas III, perlu adanya revisi penggunaan kata yang disesuaikan dengan EYD pada salah satu soal latihan yaitu kata 'pakai' menjadi 'memakai'.

Produk media pembelajaran interaktif kemudian diujicobakan ke lapangan dengan subjek yang lebih banyak. Uji coba lapangan dilakukan pada 32 siswa kelas di sekolah dasar yang berbeda dengan pada saat uji coba lapangan awal. Data yang diperoleh pada tahap ini berupa angket respon siswa dan respon guru. Hasil kuesioner respon siswa menunjukkan nilai rata-rata 4,6 dengan kategori sangat baik. Hasil ratarata nilai kuesioner respon guru adalah 4,8 dengan kategori sangat.

Tabel 6

Analisis Data Kuesioner Respon Siswa

\begin{tabular}{lc}
\hline \multicolumn{1}{c}{ Aspek } & Rata-rata \\
\hline Ketertarikan & 4,7 \\
Penyajian & 4,6 \\
Kualitas dan manfaat & 4,6 \\
Rasa ingin tahu & 4,7 \\
Kemauan berprestasi & 4,6 \\
\hline
\end{tabular}

Tabel 7

Analisis Data Kuesioner Respon Guru

\begin{tabular}{lc}
\hline \multicolumn{1}{c}{ Aspek } & Rata-rata \\
\hline Kesesuaian & 5,0 \\
Manfaat & 5,0 \\
Kelayakan & 4,0 \\
\hline
\end{tabular}

Data yang diperoleh pada saat uji coba lapangan dijadikan dasar untuk melakukan tahap penelitian yang ketujuh, yaitu penyempurnaan produk media pembelajaran interaktif pada materi Bumi dan Alam Semesta hingga diperoleh hasil akhir media pembelajaran interaktif yang akan digunakan untuk pembelajaran materi Bumi dan Alam Semesta kelas III SD. Hasil akhir dari penelitian ini adalah berupa produk media pembelajaran interaktif materi Bumi dan Alam Semesta untuk kelas III SD semester 2. Komponen media pembelajaran ini terdiri dari:

\section{Halaman awal}

Halaman awal ini merupakan halaman pembuka pada program media pembelajaran yang berisi teks "Selamat Datang di Media Pembelajaran Interaktif Materi Bumi dan Alam Semesta". Pada halaman ini dilengkapi dua tombol pilihan yaitu tombol "keluar" untuk keluar dari program dan tombol "mulai" untuk memulai pembelajaran.

\section{Halaman menu utama}

Pada bagian ini terdapat beberapa tombol pilihan yaitu menu untuk memulai pembelajaran, petunjuk, tentang program dan sumber.

\section{Halaman menu}

Bagian ini merupakan halaman pengantar untuk memilih pembelajaran. Pada halaman ini terdapat empat pilihan tombol yaitu tombol KD 6.2, tombol KD 6.3, tombol rangkuman dan tombol evaluasi.

\section{Halaman submenu}

Halaman ini merupakan pengantar untuk memulai pembelajaran materi pada kompetensi dasar 6.2 dan 6.3. Terdapat pilihan tombol SK, KD, materi, tujuan dan indikator.

\section{Halaman petunjuk}

Bagian ini berisi petunjuk penggunaan program media pembelajaran yang menjelaskan bahwa siswa harus mengerjakan setiap soal untuk dapat menyelesaikan pembelajaran.

\section{Halaman tentang program}

Halaman ini berisi informasi tentang program media pembelajaran interaktif materi bumi dan alam semesta mulai dari pembuat ide, cakupan materi, sasaran dan software yang digunakan.

\section{Halaman rangkuman}

Halaman rangkuman berisi rangkuman materi. Pada halaman rangkuman, memuat rangkuman materi dari kompetensi dasar 6.2 dan kompetensi dasar 6.3.

\section{Halaman evaluasi}

Halaman ini berisi soal-soal yang mencakup materi kompetensi 6.2 dan materi kompetensi dasar 6.3. Soal yang terdapat pada halaman evaluasi berjumlah 20 soal pilihan ganda yang dapat mengukur pemahaman siswa terhadap materi yang sudah dipelajari. Respon pada halaman evaluasi adalah muncul keterangan benar dan salah dari jawaban yang dipilih siswa pada setiap nomor. Pada bagian akhir terdapat keterangan jumlah soal yang berhasil dijawab dengan benar, jumlah soal yang dikerjakan salah, dan total skor yang diperoleh siswa.

\section{Halaman Standar Kompetensi (SK)}

Halaman standar kompetensi berisi informasi standar kompetensi mata pelajaran IPA 
kelas III semester 2 yaitu standar kompetensi 6 . Memahami kenampakan permukaan bumi, cuaca dan pengaruhnya bagi manusia, serta hubungannya dengan cara manusia memelihara dan melestarikan alam.

\section{Halaman Kompetensi Dasar (KD)}

Halaman ini berisi informasi kompetensi dasar IPA kelas III semester 2 yaitu kompetensi dasar 6.2, yang menjelaskan hubungan antara keadaan awan dan cuaca serta kompetensi dasar 6.3 yang mendeskripsikan pengaruh cuaca bagi kegiatan manusia.

\section{Halaman tujuan}

Berisi informasi tujuan pembelajaran untuk kompetensi dasar 6.2 dan kompetensi dasar 6.3.

\section{Halaman indikator}

Halaman ini berisi informasi indikator pencapaian kompetensi yang harus dicapai oleh siswa sesuai dengan KD 6.2 dan KD 6.3.

\section{Halaman materi}

Pada halaman materi berisi materi pembelajaran kompetensi dasar 6.2 dan kompetensi dasar 6.3. Model yang digunakan adalah model pembelajaran tutorial. Pada halaman ini terdapat materi dari kompetensi dasar 6.2 dan kompetensi dasar 6.3. Dilengkapi dengan latihan soal pada masing-masing kompetensi dasar 6.2 dan 6.3. Latihan soal terdiri dari soal benar salah dan soal pilihan ganda.

\section{Halaman sumber}

Pada halaman ini memuat daftar sumber yang digunakan dalam menyusun media pembelajaran interaktif ini. Daftar sumber memuat sumber materi, sumber gambar, sumber video dan sumber suara tombol yang terdapat dalam media pembelajaran interaktif ini.

Berdasarkan hasil uji validasi ahli materi dan ahli media terhadap media pembelajaran interaktif materi Bumi dan Alam Semesta sebesar 3,9 oleh ahli media dan 2,95 oleh ahli materi. Media pembelajaran ini dinyatakan layak untuk digunakan sebagai media pembelajaran materi Bumi dan Alam Semesta. Hasil rata-rata nilai kuesioner respon siswa pada uji coba lapangan awal sebesar 4,5 dengan kategori sangat baik, sedangkan hasil rata-rata nilai kuesioner respon guru sebesar 5,0 dengan kategori sangat baik. Hasil rata-rata nilai kuesioner respon siswa pada uji coba lapangan sebesar 4,6 dan hasil kuesioner respon guru sebesar 4,8 dengan kategori sangat baik menunjukkan bahwa media pembelajaran ini sangat baik dan layak untuk dijadikan media pembelajaran materi Bumi dan Alam Semesta kelas III SD semester 2. Pembelajaran dengan menggunakan media pembelajaran interaktif pada materi Bumi dan Alam Semesta pada kelas III SD ini dapat membantu siswa dalam memahami konsep materi Bumi dan Alam Semesta, karena siswa ikut aktif dalam pembelajaran dengan terlibat langsung dalam penggunaan media. Kondisi sebelum penelitian bahwa pemanfaatan TIK khususnya komputer terbatas pada pembelajaran komputer saja dan belum diterapkan untuk pembelajaran selain komputer. Sesuai karakteristik siswa SD saat ini yang fasih teknologi, penggunaan media pembelajaran interaktif yang memanfaatkan komputer sebagai perangkat utama memberikan pengalaman belajar baru bagi siswa, sehingga siswa merasa tertarik terhadap materi pembelajaran dan menumbuhkan minat siswa untuk belajar. Tidak hanya melihat dan mendengar, siswa mendapat respon langsung berupa respon jawaban benar dan salah serta nilai yang diperoleh setelah mengerjakan soal.

Sejalan dengan hasil penelitian yang dilakukan oleh Farida Hasan Rahmaibu, yang mengembangkan media pembelajaran menggunakan Adobe Flash untuk meningkatkan hasil belajar PKn pada siswa kelas IV Sekolah Dasar Islam Al Madina Semarang tahun ajaran 2015/2016. Penelitian serupa juga dilakukan oleh Tri Apriyani yang berhasil mengembangan media pembelajaran interaktif menggunakan Adobe Flash untuk meningkatkan keterampilan membaca bahasa Perancis pada siswa kelas XI SMA El Shadai Magelang. Peneliti memilih software Adobe Flash sebagai sarana dalam mengembangkan media pembelajaran seperti yang dilakukan oleh Reni Yunita yang berhasil mengembangkan multimedia kuesioner berbasis STAD yang layak digunakan sebagai media pembelajaran IPA pada materi sistem gerak manusia untuk SMP/MTs. Beberapa alasan memilih software Adobe Flash dalam mengembangkan media pembelajaran adalah kelebihan-kelebihan yang dimiliki Adobe Flash diantaranya yaitu hasil akhir file flash setelah dipublish memiliki ukuran yang lebih kecil, flash memiliki kemampuan mengimpor dan mengolah jenis file mulai dari file gambar, video dan audio sehingga memungkinkan hasil sajian materi menggunakan adobe flash menjadi lebih menarik dan hidup, animasi dapat dibuat dan dijalankan sesuai kebutuhan. Hasil file flash yang dapat berupa file "* .exe" (executable) memungkinkankan untuk menjalankan file flash pada PC tanpa harus terlebih dahulu menginstal program Adobe Flash. Hasil penelitian yang dilakukan oleh Farida Hasan Rahmaibu, dan Tri Apriyani menunjukkan keberhasilan media yang dikembangkan dalam meningkatkan hasil belajar dan keterampilan membaca bahasa Perancis dan layak 
digunakan sebagai media pembelajaran. Penulis memilih ketiga penelitian tersebut karena hasil yang ditunjukkan mendukung jika dilakukan penelitian dan pengembangan berikutnya pada lingkungan yang berbeda. Media pembelajaran yang dikembangkan menggunakan software Adobe Flash pada materi, mata pelajaran bahkan pada tingkatan kelas yang berbeda seperti dipaparkan dalam ketiga penelitian tersebut berhasil menunjukkan peningkatan pada aspek tertentu, misalnya dalam penelitian tersebut berhasil meningkatkan hasil belajar dan keterampilan membaca bahasa asing. Keberhasilan tersebut dikarenakan dengan digunakannya media pembelajaran interaktif pada pembelajaran, tentunya penyajian materi menjadi lebih menarik bagi siswa. Materi disajikan tidak terbatas dalam bentuk teks tetapi juga dalam bentuk video dan gambar-gambar yang relevan dengan materi pembelajaran. Siswa yang tadinya kurang mampu memahami materi disebabkan materi yang terlalu banyak, dapat terbantu dengan penggunaan media pembelajaran, siswa yang awalnya kurang tertarik terhadap materi pelajaran tertentu dapat meningkat ketertarikannya karena penyajian materi dalam media yang dikemas sedemikian rupa tidak hanya berbentuk teks tetapi juga video, gambar maupun bagan. Kelebihan dalam penelitian dan pengembangan ini adalah menghasilkan produk media pembelajaran interaktif yang layak digunakan pada materi bumi dan alam semesta untuk kelas III SD. Media pembelajaran interaktif yang digunakan dalam pembelajaran dapat memberikan pengalaman belajar baru bagi siswa yang meningkatkan ketertarikan siswa terhadap materi pembelajaran sehingga dapat menumbuhkan minat siswa dalam belajar. Berdasarkan hasil pembahasan penelitian yang dilakukan oleh Farida Hasan Rahmaibu, Tri Apriyani, Reni Yunita serta dalam penelitian ini menunjukkan hasil yang bervariasi. Pengembangan media pembelajaran menggunakan Adobe Flash dapat memberi dampak positif tidak terbatas pada peningkatan hasil belajar saja melainkan juga dapat meningkatkan keterampilan membaca serta hasil pada penelitian ini yang dapat meningkatkan ketertarikan siswa terhadap materi pembelajaran sehingga menumbuhkan minat siswa untuk belajar. Untuk itu, penelitian dan pengembangan media pembelajaran dengan menggunakan software Adobe Flash dapat dikembangkan pada mata pelajaran, materi, tingkatan kelas, dan lingkungan yang berbeda sesuai kebutuhan.

\section{PENUTUP}

\section{Kesimpulan}

Berdasarkan pembahasan hasil penelitian dan pengembangan media pembelajaran interaktif materi Bumi dan Alam Semesta dengan menggunakan software Adobe Flash, dapat disimpulkan bahwa (1) pembelajaran pada media ini adalah materi Bumi dan Alam Semesta mata pelajaran IPA untuk kelas III SD semester 2. Tercakup dalam media pembelajaran ini dua kompetensi dasar dari standar kompetensi 6 yaitu kompetensi dasar 6.2 dan kompetensi dasar 6.3. Media pembelajaran ini dikembangkan dengan menggunakan aplikasi Adobe Flash Profesional CS6. Dalam proses pengembangan juga menggunakan beberapa aplikasi lain seperti Video Cutter Joiner, yang digunakan untuk mengedit video yang akan dimasukkan ke dalam Flash dan Format Factory yang digunakan untuk mengubah ekstensi jenis file video yang akan digunakan. Jenis file video diubah menjadi jenis file berekstensikan flv; (2) rancangan draft awal media pembelajaran interaktif diujikan kepada para ahli yaitu ahli materi dan ahli media. Setelah diperoleh validasi dari para ahli, rancangan draft produk direvisi sesuai dengan saran yang diberikan oleh para ahli. Setelah revisi draft produk, produk media pembelajaran interaktif kemudian diuji cobakan ke lapangan yaitu uji coba lapangan awal dan uji coba lapangan; (3) media pembelajaran interaktif yang dikembangkan ini sudah layak untuk digunakan sebagai media pembelajaran berdasarkan dari hasil validasi ahli dan uji coba lapangan; (4) nilai yang diperoleh dari validasi ahli materi adalah 2,95 dan nilai dari ahli media adalah 3.9; (5) media pembelajaran interaktif ini mampu merangsang siswa aktif dalam pembelajaran dan menumbuhkan minat belajar siswa terhadap materi pembelajaran. Hal ini ditunjukkan oleh nilai rata-rata yang diperoleh dari uji coba lapangan awal adalah 4,5 untuk angket respon siswa dan 5,0 dari hasil angket respon guru. Hasil nilai rata-rata pada uji coba lapangan adalah 4,6 untuk angket respon siswa dan 4,8 untuk angket respon guru dengan kategori sangat baik.

\section{Saran}

Media pembelajaran interaktif ini disarankan agar dapat diterapkan pada pembelajaran IPA di sekolah dasar. Fasilitas sekolah yang memadai seperti tersedianya $L C D$, proyektor, dan laboratorium komputer dapat dimanfaatkan untuk menjalankan 
media pembelajaran interaktif ini secara mandiri maupun klasikal, sehingga dapat tercipta suasana pembelajaran yang praktis, interaktif dan menarik. Selain mempertimbangkan fasilitas sekolah yang sudah memadai, potensi guru dan siswa yang mampu mengoperasikan komputer hendaknya dimanfaatkan dalam pembelajaran dengan menggunakan media ini. Dengan adanya media pembelajaran interaktif ini, diharapkan siswa dapat terbantu dalam proses belajarnya. Pengembangan lebih lanjut dari produk ini, adalah (a) pengembangan media pembelajaran interaktif pada mata pelajaran IPA materi lain; (b) pengembangan media pembelajaran interaktif yang dapat menambah minat maupun kreativitas siswa sehingga meningkatkan hasil belajar siswa; dan (c) pengembangan media pembelajaran interaktif yang dapat digunakan bagi siswa-siswa berkebutuhan khusus. Media pembelajaran interaktif ini juga dapat dikembangkan untuk tingkat kelas lain selain kelas III SD dan pada mata pelajaran yang lain selain mata pelajaran IPA.

\section{DAFTAR PUSTAKA}

Apriyani, T. (2015). Pengembangan media pembelajaran interaktif Adobe Flash CS5 untuk meningkatkan keterampilan membaca teks pendek bahasa prancis siswa kelas XI SMA El Shadai Magelang. Disertasi. Universitas Negeri Yogyakarta.

Arikunto, S. (2013). Prosedur penelitian suatu pendekatan praktik. Jakarta: Rineka Cipta.

Darmawan, D. (2012). Inovasi pendidikan: pendekatan praktik teknologi multimedia dan pembelajaran online. Bandung: Remaja Rosdakarya.

Hasan, A. M. (2003). Pengembangan profesionalisme guru di abad pengetahuan. Malang: PPS Universitas Negeri Malang. Diakses melalui http://www. tcpdf.org pada tanggal 18 Oktober 2011.

Indriana, D. (2011). Ragam alat bantu media pengajaran. Yogjakarta: Diva Press.

MADCOMS. (2013). Adobe Flash CS6. Yogyakarta: Andi Offset.

Mawardi. (2018). Merancang model dan media pembelajaran. Scholaria: Jurnal Pendidikan dan Kebudayaan, 8(1), Januari 2018 , 26-40.

Prayogo, P. D. (2015). Pengembangan multimedia interaktif tematik untuk siswa kelas IV SD Muhammadiyah Condongcatur. E-Jurnal Skripsi Mahasiswa TP, (7).
Puspitasari, R. N. (2010). Upaya peningkatan prestasi belajar IPA siswa kelas III melalui penerapan metode guided inquiry-discovery. Disertasi. UNS.

Radia, E. H. (2016). Upaya meningkatkan hasil belajar pada siswa kelas III melalui model belajar kontekstual berbantuan media benda konkret pada mapel Ilmu Pengetahuan Alam di SD Negeri Sidorejo Kidul 03 semester I tahun ajaran 2016/2017. Disertasi. Program Studi Pendidikan Guru Sekolah Dasar FKIP-UKSW.

Rahmaibu, F. H., Ahmadi, F., \& Prasetyaningsih, F. D. (2017). Pengembangan media pembelajaran menggunakan adobe flash untuk meningkatkan hasil belajar PKn. Jurnal Kreatif: Jurnal Kependidikan Dasar, 7(1).

Sa'ud, U. S. (2012). Inovasi pendidikan. Bandung: Alfabeta.

Sanoto, H., \& Pulungan, D.S. (2014). Pengembangan pembelajaran IPA SD. Salatiga: Widya Sari Press.

Slameto. (2011). Pengembangan model pembelajaran kreatif untuk meningkatkan prestasi belajar siswa Kelas IV SD RSBI Kota Salatiga. Satya Widya : Jurnal Penelitian Pengembangan Kependidikan, Vol. 27, No. 1, Juni 2011, p. 111 - 135.

Slameto. (2015). Generation Z and the implications for counseling. Proceeding Seminar and Workshop Mid Year APECA 2015 in Salatiga. Diakses melalui http:// repository.uksw.edu/handle/123456789/6862.

Slameto., N. S. Wardani, \& F Kristin. (2016). Pengembangan model pembelajaran berbasis riset untuk meningkatkan keterampilan berpikir aras tinggi. Prosiding Konser Karya Ilmiah Nasional 2016. "Komunikasi Hasil Riset, Pengabdian Masyarakat, dan Produk-Produk Unggulan yang Berdaya Saing". Diakses melalui http:// repository.uksw.edu/handle/123456789/8688.

Sukarno. (1981). Dasar-dasar pendidikan sains. Jakarta: Bhatara Karya Aksara.

Suyono \& Hariyanto. (2014). Belajar dan pembelajaran. Bandung: Remaja Rosdakarya.

Undang-Undang Republik Indonesia No 20 Tahun 2003 tentang sistem pendidikan.

Yunita, R. (2017). Pengembangan multimedia adobe flash CS5 berbasis STAD sebagai media pembelajaran IPA pada pokok bahasan sistem gerak pada manusia untuk SMP/MTs. Disertasi. IAIN Raden Intan Lampung. 